\title{
Naclerio's V sign and continuous diaphragm sign after endoscopy
}

\author{
Yohei Komaru, ${ }^{1}$ Akinori Maeda ${ }^{2}$
}

'Division of Nephrology and Endocrinology, The University of Tokyo Hospital, Tokyo, Japan ${ }^{2}$ Department of Acute Medicine, The University of Tokyo Hospital, Tokyo, Japan

\section{Correspondence to Dr Yohei Komaru, \\ komaru-tky@umin.ac.jp}

Accepted 3 September 2018

\section{DESCRIPTION}

An otherwise healthy 72-year-old woman presented with dyspnoea and systemic subcutaneous emphysema. She had undergone upper endoscopy, in which duodenal ulcer was found. The community hospital where the endoscopy was conducted transferred her to our tertiary hospital for further diagnosis and management. On arrival, she complained of severe difficulty in breathing; massive subcutaneous emphysema on her chest to the feet was observed on palpation. Chest X-ray image showed Naclerio's V sign (figure $1 \mathrm{~A}$, black arrow) and continuous diaphragm sign (figure 1A, white arrows). CT scan confirmed massive subcutaneous and mediastinal emphysema with pneumothorax, pneumopericardium and free air in retroperitoneal space (figure $1 \mathrm{~B}, \mathrm{C}$ ). Emergent laparotomy revealed duodenal perforation, $9 \mathrm{~mm}$ in diameter at the descending part of duodenum (figure 1D, white arrow), and was surgically repaired. After the surgery, the emphysema gradually disappeared in weeks and had not recurred at 6-month follow-up.

Endoscopic or surgical procedures can induce gastrointestinal perforation as its complication. Depending on the perforated site, it would result in different clinical findings such as pneumoperitoneum, ${ }^{1}$ pneumopericardium, ${ }^{2}$ pneumothorax and mediastinal emphysema. Except for its proximal portion next to the stomach, most part of the duodenum is buried into retroperitoneal space. Thus, a duodenum perforation can induce retroperitoneal emphysema as in the present case, or pneumoperitoneum otherwise, depending on the perforation site. Naclerio's V sign, which was originally reported as a sign indicating spontaneous oesophageal rupture, ${ }^{3}$ sometimes gives us a clue of mediastinal emphysema on the chest plain film. Rapid diagnosis of gastrointestinal tract perforation generally leads to prompt surgical intervention, which is required to realise better outcome.
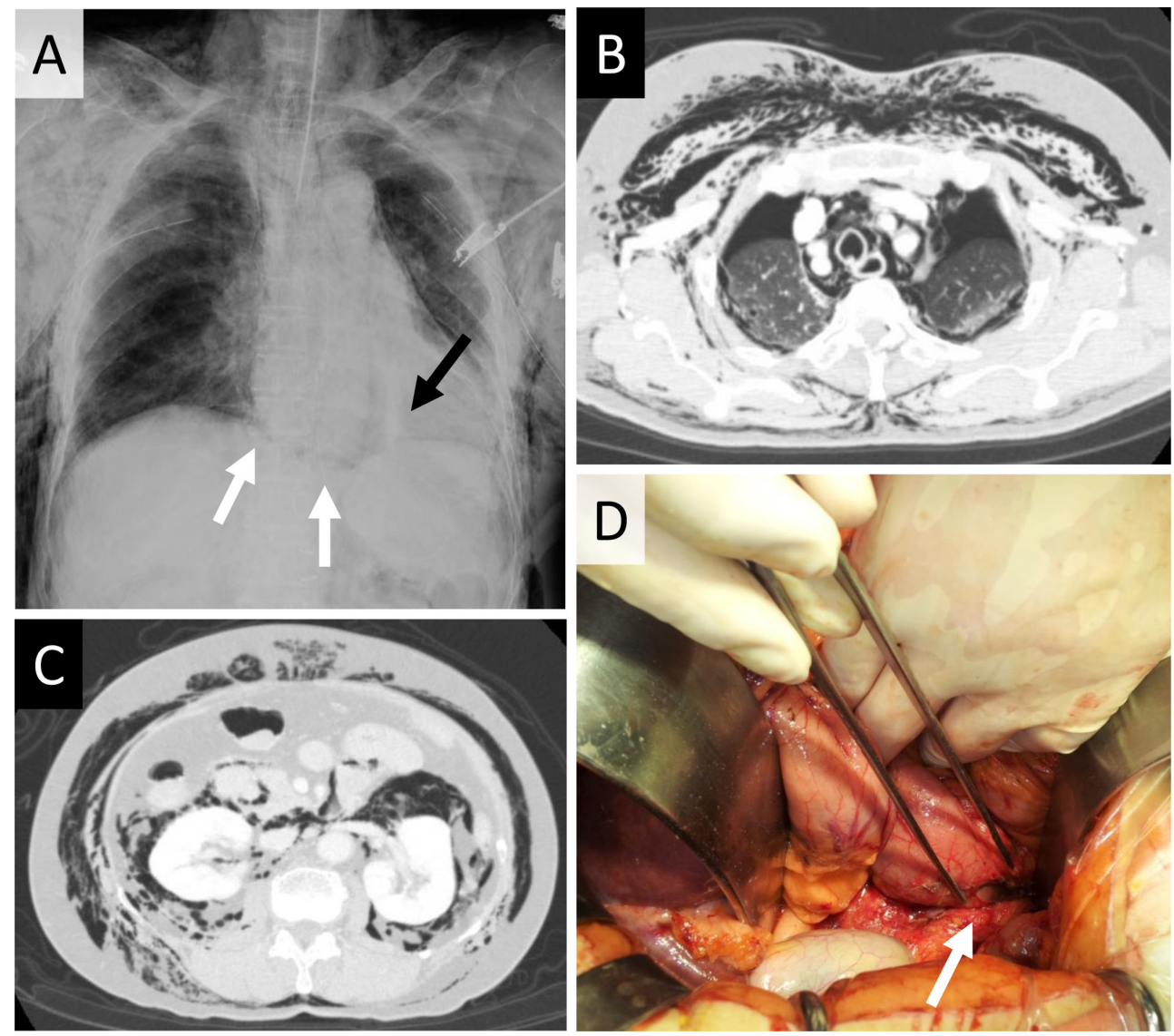

Figure 1 (A) Plain chest radiograph with Naclerio's V sign (black arrow) and continuous diaphragm sign (white arrows). (B) CT image showing pneumothorax, pneumomediastinum and subcutaneous emphysema. (C) Free air was observed in retroperitoneal space. (D) Duodenal perforation (white arrow) was revealed in laparotomy.

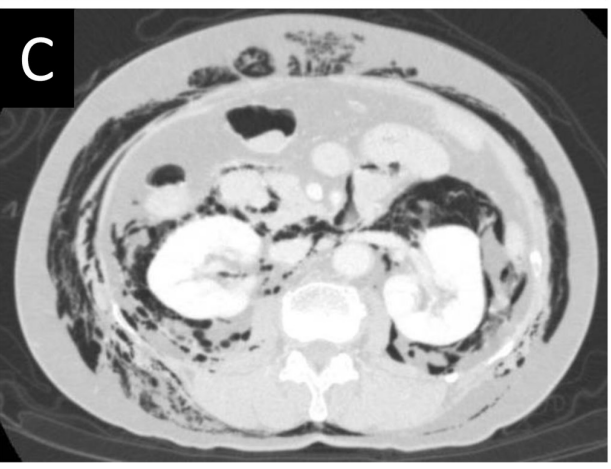

(c) BMJ Publishing Group Limited 2018. No commercial re-use. See rights and permissions. Published by BMJ.

To cite: Komaru Y, Maed
BMJ Case Rep Published Online First: [please include Day Month Year]. doi:10.1136/bcr-2018226021 


\section{Learning points}

Remember gastrointestinal perforation as a complication of endoscopic procedure.

- A duodenum perforation can induce either retroperitoneal emphysema or pneumoperitoneum, depending on the perforation site.

- Physicians should suspect upper gastrointestinal perforation when they encounter specific signs in plain X-ray image: Naclerio's V sign and/or continuous diaphragm sign.

Contributors YK and AM contributed to the patient's management and drafting of the manuscript. All the authors approved the manuscript prior to submission.
Funding The authors have not declared a specific grant for this research from any funding agency in the public, commercial or not-for-profit sectors.

Competing interests None declared.

Patient consent Obtained.

Provenance and peer review Not commissioned; externally peer reviewed.

\section{REFERENCES}

1 Kaafarani HM.Images in clinical medicine. Tension Pneumoperitoneum. N Engl J Med 2015:373:e24.

2 Karoui M, Bucur PO. Images in clinical medicine. Pneumopericardium. N Engl J Med 2008;359:e16.

3 Naclerio EA.The $\mathrm{V}$ sign in the diagnosis of spontaneous rupture of the esophagus (an early roentgen clue). Am J Surg 1957;93:291-8.

Copyright 2018 BMJ Publishing Group. All rights reserved. For permission to reuse any of this content visit

http://group.bmj.com/group/rights-licensing/permissions.

BMJ Case Report Fellows may re-use this article for personal use and teaching without any further permission.

Become a Fellow of BMJ Case Reports today and you can:

- Submit as many cases as you like

- Enjoy fast sympathetic peer review and rapid publication of accepted articles

- Access all the published articles

- Re-use any of the published material for personal use and teaching without further permission

For information on Institutional Fellowships contact consortiasales@bmjgroup.com

Visit casereports.bmj.com for more articles like this and to become a Fellow 